\title{
An Overview of Yield-to-Bus Programs in Florida
}

\author{
Huaguo Zhou, Southern Illinois University Edwardsville \\ Stephanie Bromfield, National Works Agency \\ Pei-Sung Lin, University of South Florida
}

\begin{abstract}
This paper presents an overview of Yield-to-Bus (YTB) programs in Florida, including a review of bus operator surveys, operational and safety effects of YTB signage, and Florida YTB statutes. The statewide bus operators' survey highlighted different aspects of YTB programs in Florida. First, it was apparent that bus operators often have difficulty moving back into the flow of traffic from any off-line position, including bus pullout bays, right-turn lanes, and wide paved shoulders. Even with the law implemented, motorists typically do not yield to the bus. The study found that the decal currently implemented on the back of the bus has no significant safety or operational effects, and there are no roadside signs or pavement markings for YTB laws.
\end{abstract}

\section{Introduction}

According to previous studies, a high percentage of bus crashes in Florida are caused by rear-end collisions with private automobiles. A 2004 study done by Luke Transportation Engineering (Luke Transportation Engineering Consultants, Inc. 2004) showed that the most common cause of bus crashes was inattentive or careless driving on the part of private automobile operators. The transit agencies surveyed in this study recommended the installation of more bus pull-out bays on state roads, more effective lighting configurations on the rear of buses, and statewide bus stop design standards (Luke Transportation Engineering Consultants, Inc. 2004). The Luke 
Transportation Engineering study put high crash locations into four categories, one being crash records that included a public transit bus within $80 \mathrm{ft}$ of a bus stop or bus station (Category 4). Bus accidents in Category 4 accounted for 47 percent of the severe crashes that occurred within the visual influence or the rear of the bus. Having buses pull into a specially-designated pull-out bay may reduce these rear-end collisions; however, operators often complain of the difficulty in returning to the flow of traffic. This may be the impetus for the yield-to-bus (YTB) law.

YTB legislation was enacted in Florida in 1999. Florida Statute 316.0815 states that "vehicles must yield the right-of-way to a publicly owned transit bus traveling in the same direction which has signaled and is reentering the traffic flow from a specifically designated pull-out bay. The operator of the bus must also drive with due regard for the safety of all persons using the roadway." This is commonly referred to as the YTB law. Transit agencies throughout Florida have implemented this law in several ways, but the most common application includes a single decal placed on the back of the bus.

\section{YTB Legislation}

In the United States, seven states have passed laws requiring motorists to yield to buses attempting to merge back into traffic, including Florida, Washington, Oregon, New Jersey, California, and Minnesota; Colorado recently passed a law to allow transit agencies to post LED yield signs on the backs of buses and require drivers to yield the right-of-way to transit buses entering traffic.

The laws vary in requirements for transit agencies and the circumstances under which motorists are required to yield. No fines or penalties have been specified for violators of these laws, and they are largely unenforced. Oregon, Washington, Minnesota, and Florida share the basic elements of the law by stating that motor vehicles should yield to publicly-owned transit buses. Oregon, Washington, and Florida also state that the bus driver should operate with due regard for the safety of all persons using the roadway. Oregon and California, however, are more specific by defining the yield signal. They also class overtaking a bus as failure to yield the right-of-way under certain conditions. Originally, the New Jersey bill for the new YTB law specified a yield sign, but this was omitted from the law in 2004. A survey conducted for bus operators in Florida showed that over 60 percent of the bus drivers felt that very few motorists were aware of YTB laws. In Washington State, where the law was in existence before the Florida law, 40 percent of operators felt that very few motorists were aware of YTB laws (King 2003). 
The Manual on Uniform Traffic Devices (MUTCD) (Federal Highway Administration 2009) does not address traffic control devices for the YTB law; however, it does specify pavement markings, signs for yielding at intersections, yielding for pedestrians, and yielding for bicyclists.

\section{Methodology}

To understand the impacts of the YTB laws in Florida, a statewide bus operators' survey was conducted to evaluate bus operators' perceptions of the law, as well as the effectiveness of different signs and lights. To supplement bus operator surveys, field data were collected at eight locations in three Florida counties.

\section{Bus Operator Survey}

The questionnaire was divided into three sections. The first section consisted of questions pertaining to bus operations and perceived motorist yield behavior. The second section pertained to different technologies available on the back of the bus for merging the bus back into traffic safely. The third section pertained to the current Florida laws and any additional safety concerns. At the end of the questionnaire was a narrative portion where bus operators were able to make recommendations for their own bus safety program as well as any additional comments and concerns.

\section{Field Observations}

To supplement bus operator surveys, observations in the field can provide valuable information on current conditions and driver behavior. Three variables that can be recorded in the field are re-entry delay, yield behavior, and conflicts.

\section{Re-Entry Delay}

Re-entry delay is the amount of time a bus waits before finding a suitable gap to reenter the traffic stream. Re-entry delay is the variable portion of the clearance time. The clearance time is defined as the minimum time required for one bus to accelerate out of and clear the loading area and for the next bus to pull into the loading area, including any time spent waiting for a gap in traffic (Kittelson \& Associates, Inc. 2003). Part of the clearance time is fixed and consists of the time it takes the bus to start up and travel its own length. The variable part of clearance time is apparent only for off-line stops when a bus must wait for a suitable gap in traffic. The Transit Capacity and Quality of Service Manual suggests that in states with YTB laws, the re-entry delay can be minimized or eliminated depending on how well motorists comply with the laws (Kittelson \& Associates, Inc. 2003). 


\section{Conflict Study and Yield Behavior}

A conflict study can be used to determine hazardous locations and situations. A traffic conflict is a situation in which a collision would have occurred if road users had continued with unchanged speeds and directions. Counting the number of serious conflicts that occur at a location can be used to determine the level of traffic hazard (DeLangen and Tembele 1994). Traffic Conflict Techniques (TCTs) have been developed in a number of European and North American countries to add relevant information to existing accident data or to replace missing accident data (Muhlrad 2007). A conflict is often determined by an abrupt braking maneuver; vehicle tail-lights are observed and any rapid deceleration is noted.

Yield behavior is determined by reviewing videos recorded in the field. A traffic conflict due to improper yield behavior is determined by the observer and is a subjective measure of traffic safety. Yield behavior may vary by location since intersections affect driver behavior. Yield behavior at mid-block locations are, therefore, expected to be different than at far-side and near-side bus stops.

\section{Data Collection}

\section{Bus Operator Survey}

Preliminary bus operator questionnaires were distributed at the State Bus Roadeo in Jacksonville, Florida, in March 2007. Additional surveys were conducted at the bus operator facilities for LYNX in Orange County and Hillsborough Area Regional Transit (HART) in Hillsborough County. At these locations, questionnaires were completed in two ways: questions were read directly to the bus operator and the responses were completed by the person administering the survey, or surveys were handed directly to the bus operator to be completed. Surveys were conducted at LYNX on Wednesday, March 28, 2007, between 12 noon and 2 PM. HART surveys were conducted on Thursday, April 26, 2007, between 2 PM and 4 PM. Data collection dates and times were suggested by transit agency supervisory staff. The method of survey administration also was dependent on the preference of transit agency staff. Additional questionnaires were left at the LYNX and HART facilities for operators who were not present at the time of the survey but wished to participate. The additional LYNX questionnaires were mailed back, while the HART questionnaires were collected at a later date.

Additional questionnaires were mailed and e-mailed to transit agencies for responses to be mailed back when completed by the bus operators. Mailed questionnaires were received from Lee County Transit (Lee Tran), Volusia County Transit (VOTRAN), 
Pinellas Suncoast Transit Authority (PSTA) in Pinellas County, and Star Metro in Leon County, all in Florida. Surveys from Lee County and Volusia County were completed between March and April 2007. Surveys from Pinellas County were completed in May 2007, and surveys from Leon County were completed between May and June 2007.

The transit agencies chosen for the survey represented a range of practices in Florida. The Jacksonville Transportation Authority (JTA) in Duval County did not have any YTB decals or LED lights; therefore, their responses represented operators who were not using any YTB technologies. PSTA and HART both had YTB decals on their entire fleet; therefore, their responses represented agencies with a widely-used YTB technology. LYNX in Orange County had three different YTB decals, but they were not installed on all buses. Operators from LYNX were able to compare the different YTB decals and comment on their effectiveness. Lee Tran used both YTB decals and "Yield" LED signs but not on their entire bus fleet. VOTRAN never had any YTB decals, but they did have "Yield" LED lights on a few of their buses. Lee Tran and VOTRAN represented the only agencies in Florida that employed a technology other than the decal for YTB laws.

A total of 277 bus operator questionnaires representing 12 counties were obtained. Only one questionnaire was received from Polk, Manatee, Broward, Brevard and Alachua counties during the preliminary survey in March 2007; therefore, information from these counties was not greatly represented. Table 1 shows the transit agencies and the number of responses received.

Table 1. Transit Agencies Surveyed

\begin{tabular}{|l|c|c|}
\hline Transit Agency & County & Number of Participants \\
\hline Regional Transit System & Alachua & 1 \\
\hline Space Coast Area Transit & Brevard & 1 \\
\hline Broward County Transit & Broward & 1 \\
\hline Jacksonville Transportation Authority & Duval & 12 \\
\hline Hillsborough Area Transit Authority & Hillsborough & 27 \\
\hline Lee Tran & Lee & 22 \\
\hline Starmetro & Leon & 44 \\
\hline Manatee County Area Transit & Manatee & 1 \\
\hline LYNX & Orange & 29 \\
\hline Pinellas Suncoast Transit Authority & Pinellas & 112 \\
\hline Polk County Transit Services & Polk & 1 \\
\hline VOTRAN & Volusia & 26 \\
\hline
\end{tabular}




\section{Field Observation}

Field data were collected using a video camera positioned at an appropriate distance to capture buses moving in and out of bus pull-out bays. Locations, therefore, had to be selected where a camera could be mounted and positioned with a clear view of the buses and cars. Far-side bus stop locations posed a particular challenge since the camera had to be located across the intersection. At certain times, the cross street traffic blocked the view of the buses at the far-side.

\section{Site Selection}

Three locations were chosen in Hillsborough County for field studies of HART buses, and three locations were also chosen in Orange County for field studies of LYNX buses. From each county, one far-side, one mid-block, and one near-side bus stop were studied. The locations were chosen based on traffic conditions and the existence of a bus pull-out bay. The locations chosen in Orange County were based on recommendations by LYNX staff.

Field studies in Hillsborough County were conducted during the afternoon peak hours on a typical weekday in December 2006. Field studies in Orange County were conducted during morning and afternoon peak-hours in April 2007. At least three hours of video were recorded at each location. Table 2 shows the sites selected for field data collection.

\section{Table 2. Site Locations}

\begin{tabular}{|l|l|c|c|}
\hline County & Location & Location Type & 2006 AADT \\
\hline Hillsborough & Fletcher Ave and Bruce B Downs Blvd & Near-side & 23,500 \\
\hline Hillsborough & Hillsborough Ave and Florida Ave & Far-side & 29,500 \\
\hline Hillsborough & Fletcher Ave and Dale Mabry Blvd & Mid-block & 21,000 \\
\hline Orange & Kirkman Rd and Conroy Rd 1 & Near-side & 30,000 \\
\hline Orange & Kirkman Rd and Conroy Rd 2 & Far-side & 30,000 \\
\hline Orange & Orange Blossom Tr and Holden Ave & Mid-block & 33,500 \\
\hline
\end{tabular}

\section{Conflict, Yield Behavior, and Re-entry Delay}

From the videos taken in the field, the re-entry delay, conflicts, and yield behavior of motorists were recorded. Different types of conflicts were observed in the field, including hard braking maneuvers and weaving into oncoming traffic. Changing lanes behind the bus into a clear lane was considered a minor conflict. Secondary conflicts were created when motorists weaved into another lane, causing drivers 
in that lane to abruptly apply the brakes. Yield behavior was determined by cars slowing down to allow the bus back into traffic.

The purpose of the YTB law is to make motorists yield to the bus when it attempts to re-enter traffic from a specifically-designated bus pull-out bay. The number of motorists who passed a bus attempting to merge back into traffic also was used as a measure of yield behavior. The number of motorists who passed a bus attempting to merge is dependent on several variables, including the traffic volume, road geometry, and general visibility of the bus. The travel speed and awareness of the YTB law also influence motorist yield behavior.

Motorist yield behavior has a significant impact on the re-entry delay of buses. The re-entry delay for this study was used to evaluate the difficulty of bus operations in traffic. The re-entry delay of buses with different YTB technologies was compared to ascertain whether there was any noticeable difference in motorist reaction to merging buses with and without YTB decals.

\section{Data Analysis}

\section{Survey Results}

According to the survey results, most (74\%) bus operators had bus pull-out bays on their routes. A significant number of bus operators also use wide shoulders or rightturn lanes to pull out of through-traffic while loading and unloading passengers. Over 90 percent said they have difficulty moving back into traffic at least some of the time, and over 70 percent of operators responded that few people yield to the bus re-entering traffic.

Based on the literature review, electronic signs on the back of the bus are favored more than the decals. The bus operator survey produced these similar results. When asked which technology they preferred, the majority (73\%) chose the LED merging sign. The bus operators perceive the electronic sign to be more helpful in bus operations, and they also perceive it to help with safety more than the decal. The only positive responses for the decals were in mentions of the large 69-inch decal present on some of the LYNX buses in Orlando. When asked if there was a noticeable difference in motorist yield behavior compared to before the implementation of the YTB technology, the bus operators with experience using the decal were more inclined to answer negatively. 
In the narrative portion of the questionnaire, the most common recommendation for a bus safety program was better police enforcement of the laws and more public service announcements about the presence of the YTB laws. Other recommendations made by the bus operators were to install stop arms similar to school bus stop arms and to improve the existing lighting and signs on the back of the bus. When asked about the current Florida laws, 50 percent of bus operators felt that the current laws were insufficient, and 5 percent had no response. When asked about the conditions in which motorists should yield to the bus, 76 percent of operators felt that there are other conditions in which motorists should yield, apart from at specifically-designated bus bays. Table 3 shows a summary of the questionnaire results.

\section{Field Observations}

From the field data collected, it was apparent that the location of the bus pull-out bay and the traffic volume affected the yield behavior of other motorists. Far-side bus stop locations had the unique problem of being located where drivers would have to yield in the physical area of the intersection to allow buses to enter. Motorists, therefore, never yielded to the bus at a far-side stop unless the bus did not use the pull-out bay, forcing traffic to accumulate behind the bus. This location may be a dangerous place to attempt to yield since motorists do not expect other motorists to slow down in the middle of an intersection.

As expected, more conflicts were observed with smaller headways. It appears from these results that delay and yield behavior are dependent on a variety of variables, which may include the number of lanes, location of bus stop, hourly traffic volumes, speed, and the public's attitude towards buses in that specific location. It should be noted that when traffic volumes increase, the re-entry delay will significantly increase.

Dangerous weaving and conflicts were observed as cars attempted to move out of the outside travel lane to avoid buses that are merging into traffic. There appears to be no difference in motorist yield behavior with the presence of a decal. The observed weaving behavior often caused conflicts with other vehicles on the road, not only buses. The number of conflicts observed during a specific time period was dependent on the traffic conditions and headway of the bus. The field study indicated that higher traffic volumes and smaller headways will increase the number of conflicts. 
Table 3. Questionnaire Results

\begin{tabular}{|c|c|}
\hline RESPONSE & PERCENTAGE \\
\hline \multicolumn{2}{|c|}{ Are there any bus pull-out bays on any of the bus routes you have been assigned? } \\
\hline Yes & 74.4 \\
\hline No & 20.9 \\
\hline No response & 4.7 \\
\hline \multicolumn{2}{|c|}{$\begin{array}{l}\text { Do you ever have difficulty while attempting to merge back into traffic } \\
\text { when the bus is out of the traffic lane? }\end{array}$} \\
\hline Always & 39.4 \\
\hline Most of the time & 30.7 \\
\hline Some of the time & 24.2 \\
\hline Rarely & 3.2 \\
\hline Never & 0.7 \\
\hline No response & 1.8 \\
\hline \multicolumn{2}{|c|}{$\begin{array}{l}\text { Is there a noticeable difference in the percentage of motorists who would yield to the bus } \\
\text { as it attempts to merge before the implementation of the decal? }\end{array}$} \\
\hline No decal & 7.9 \\
\hline Yes & 26.7 \\
\hline No & 52.3 \\
\hline No response & 13.0 \\
\hline \multicolumn{2}{|c|}{$\begin{array}{l}\text { Which of these yield-to-bus signs do you think would be most effective } \\
\text { for bus operations and improved safety? }\end{array}$} \\
\hline Decal & 9.0 \\
\hline Flashing yield sign & 7.2 \\
\hline Merge alert & 73.3 \\
\hline Two technologies & 4.7 \\
\hline No response & 5.8 \\
\hline \multicolumn{2}{|c|}{$\begin{array}{l}\text { Do you think that the current Florida Statutes are sufficient } \\
\text { for increasing the safety of bus operations? }\end{array}$} \\
\hline Yes & 45.5 \\
\hline No & 49.5 \\
\hline No response & 5.1 \\
\hline \multicolumn{2}{|c|}{$\begin{array}{l}\text { Do you think there may be other conditions in which motorists should yield to a public transit bus } \\
\text { apart from when the bus is re-entering from a specially designed pull-out bay? }\end{array}$} \\
\hline Yes & 75.5 \\
\hline No & 18.5 \\
\hline No response & 6.1 \\
\hline
\end{tabular}


There were no occurrences observed of drivers yielding to the bus. The only time drivers were seen yielding to a bus that has signaled to merge into traffic was during congested traffic conditions where bus operators could merge in-between two stopped cars. In this scenario, there were no conflicts recorded, which was the situation often observed at the Florida Ave and Hillsborough Ave location in Hillsborough County. Table 4 shows a summary of the observations in the field.

Table 4. Field Data Collected

\begin{tabular}{|l|l|l|c|c|c|c|c|}
\hline County & Location & $\begin{array}{c}\text { Location } \\
\text { Type }\end{array}$ & $\begin{array}{c}\text { Peak } \\
\text { Hour } \\
\text { Volume } \\
\text { per Lane }\end{array}$ & $\begin{array}{c}\text { Average } \\
\text { Re-entry } \\
\text { Delay (s) }\end{array}$ & $\begin{array}{c}\text { Average } \\
\text { Headway } \\
\text { (mins) }\end{array}$ & $\begin{array}{c}\text { Avg. \# } \\
\text { Cars } \\
\text { Conflicts } \\
\text { Per Hour }\end{array}$ & $\begin{array}{c}\text { After Left } \\
\text { Signal }\end{array}$ \\
\hline Hillsborough & $\begin{array}{l}\text { Fletcher Ave } \\
\text { and Bruce B } \\
\text { Downs Blvd }\end{array}$ & Near-side & 1,106 & 13 & 22 & 0.50 & 9 \\
\hline Hillsborough & $\begin{array}{l}\text { Hillsborough } \\
\text { Ave and } \\
\text { Florida Ave }\end{array}$ & Far-side & 1,388 & 32 & 30 & 0 & 6 \\
\hline Hillsborough & $\begin{array}{l}\text { Fletcher Ave } \\
\text { and Dale } \\
\text { Mabry Blvd }\end{array}$ & $\begin{array}{l}\text { Mid- } \\
\text { block }\end{array}$ & 988 & 15 & 34 & 0.90 & 3 \\
\hline Orange & $\begin{array}{l}\text { Kirkman Rd } \\
\text { and Conroy } \\
\text { Rd 1 }\end{array}$ & Near-side & 859 & 13 & 24 & 0.20 & 10 \\
\hline Orange & $\begin{array}{l}\text { Kirkman Rd } \\
\text { and Conroy } \\
\text { Rd 2 }\end{array}$ & Far-side & 859 & 13 & 25 & 0.80 & 0 \\
\hline Orange & $\begin{array}{l}\text { Orange Blos- } \\
\text { som Tr and } \\
\text { Holden Ave }\end{array}$ & Mid- & 959 & 36 & 9 & 2.25 & 9 \\
\hline
\end{tabular}

\section{Summary and Discussion}

The statewide bus operator survey highlighted different aspects of the YTB program in Florida. First, it was apparent that bus operators often have difficulty moving back into the flow of traffic from any off-line position, including bus pull-out bays, right-turn lanes and wide paved shoulders. Even with the law implemented, motorists typically do not yield to the bus. The study found that the decal currently implemented on the back of the bus has no significant safety or operational effects, and there are no roadside signs or pavement markings for YTB laws. 
From video collected in the field, the literature review, and survey results, the following is an overview of the issues observed with the YTB program in Florida and recommendations to improve the practice.

\section{Signage and Lighting Configurations}

Although a basic configuration is observed based on National Highway Traffic Safety Administration (NHTSA) standards, the colors and types of lights vary greatly within the limits of NHTSA. The amber strobe lights can be confused with turning signals if only half of the bus rear is visible, which is the situation at some bus bay locations. In this situation, it is difficult to tell if a bus is stopped and picking up passengers or trying to merge into traffic. The typical motorist does not have time to decipher the bus's actions; therefore, guidelines are needed for the placement of optional lights on the back of the bus.

The majority of bus operators surveyed preferred a flashing sign with the word "MERGING." This technology has been proposed but is awaiting approval from NHTSA. If this technology is implemented, clear guidelines are needed as to what other optional lighting can be added to the bus. If a dynamic LED sign is placed on the back of the bus, it probably should not be used simultaneously with flashing hazard lights or deceleration lights.

\section{Roadside Signs}

Since the MUTCD currently has no signage or pavement markings for the YTB law, new signage and pavement markings should be developed based on the existing practices for yielding to pedestrians and bicyclists. Many roads are already congested with roadway signs and pavement markings that give drivers more information than they are able to digest; therefore, additional signs and pavement markings should be used with caution. Additional signs and pavement markings for the YTB law should be used under strict engineering judgment in areas where other measures may have failed.

Additionally, flashing beacons that are activated by a bus in a bus pull-out bay can be explored. One limitation of the beacon is that it can be installed only at midblock bus stop locations where it will not conflict with intersection lights.

\section{Yield-to-Bus Laws}

The current Florida statutes make no mention of how the YTB law is to be implemented, and this possibly contributes to the lack of law enforcement. Taking the example of other states, the Florida Statute could be expanded to include a penalty for not yielding to a bus or a classification for the type of offense committed. The 
viability of the law is partially dependent on how well it can be enforced; therefore, adding more information on the implementation and penalties may be beneficial. Other states require a public awareness campaign to inform motorists about the YTB laws; this is something that can be pursued in Florida. As in other states, a system should be set up to evaluate the necessity of the law based on the total number of traffic collisions, traffic congestion issues, public opinion, and the efficiency of transit operations.

According to the bus operator survey, the majority of operators believe that there are other conditions in which motorists should yield to a public transit bus. The bus operators also reported that they use shoulders and right-turn lanes to pull out of traffic, not just the specifically-designated bus pull-out bay. A detailed look into Florida bus crashes and delay problems can be used to determine whether it is necessary for motorists to yield under other conditions. Other states have not specified that motorists should yield at specifically-designated bus pull-out bays, therefore buses that pull over in any off-line stop would be covered under the laws. Removing the requirement of a designated bus bay could be considered since some counties do not have many bus bays, but still have difficulty merging into traffic after loading and unloading passengers.

\section{Acknowledgments}

This research was funded under contract with the Florida Department of Transportation. The authors wish to thank FDOT project manager Amy Datz for her suggestions and assistance.

\section{References}

DeLangen, M., and R. Tembele. 1994. Guidelines for pedestrian and bicycle traffic in African cities. SSATP Urban NMT Studies, E \& S Africa, Report 2, Sub-Saharan Africa Transport Policy Program.

Federal Highway Administration. 2009. Manual on Uniform Traffic Devices. U.S. Department of Transportation, Washington, D.C.

King, R. D. 2003. TCRP Synthesis 49: Yield-to-bus - State of the practice. TRB, Transportation Research Council, Washington D.C. 
Kittelson \& Associates, Inc. 2003. Transit Capacity Quality of Service Manual, 2nd Ed. TCRP Report 100, Transit Cooperative Research Program, Transportation Research Board, Washington, D.C.

Luke Transportation Engineering Consultants, Inc. 2004. Florida state highway system transit safety study. Florida Department of Transportation.

Muhlrad, N. 2007. Traffic conflict techniques and other forms of behavioural analysis: Application to safety diagnoses. 6th ICTCT workshop Salzburg Proceedings. Available at http://www.ictct.org/workshops/93-Salzburg/Muhlrad.pdf. Accessed July 10.

\section{About the Authors}

Huaguo Zhou, Ph.D., P.E. (hzhou@siue.edu) is an assistant professor in the Department of Civil Engineering at Southern Illinois University Edwardsville. He holds a Ph.D. in Transportation Engineering from the University of South Florida and a bachelor's degree and Ph.D. in Railway Engineering from Beijing Jiaotong University. His areas of interest include traffic operations, highway and transit safety, computer simulation, access management, and incident management.

StePhANIE BROMfIELD, E.I. (santoinette@gmail.com) is a highway planning engineer at the National Works Agency in Jamaica. She received a master's degree in civil engineering from the University of South Florida, where she was a graduate research assistant for several research projects including pedestrian and bicycle safety, ITS, and travel demand management.

Pei-Sung Lin, Ph.D., P.E. (lin@cutr.usf.edu) is a program director at the Center for Urban Transportation Research at the University of South Florida. He obtained his Ph.D. from the University of Florida, is a registered Professional Engineer in Florida, and currently serves as Chair of the Intelligent Traffic Signal Operations Committee of ITE. His research interests are traffic signal operations, ITS, incident management, traffic safety, public transportation, traffic simulation, and congestion management. 